\title{
Maternal Thyroid Dysfunctions and Neonatal Bone Maldevelopment
}

\author{
Ahmed R.G. \\ Division of Anatomy and Embryology, Zoology Department, Faculty of Science \\ Beni-Suef University, Beni-Suef, Egypt \\ ahmedragab08@gmail.com
}

\section{LETTER TO EDITOR}

Thyroid hormones (THs) play an essential role during the fetal and neonatal development (Gereben et al., 2008; Namba et al., 2008; El-bakry et al., 2010; Ahmed, 2011, 2012a,b, 2013, 2014, 2015a-c, 2016a-d, 2017a-v, 2018a-i; Ahmed et al., 2008, 2010, 2012, 2013a,b, 2014, 2015a,b, 2018; Ahmed and Ahmed, 2012; Ahmed and Incerpi, 2013;Van Hercket al., 2013; Ahmed andEl-Gareib, 2014,Incerpi et al., 2014; Candelotti et al., 2015; De Vito et al., 2015; El-Ghareeb et al., 2016; Ahmed and El-Gareib, 2017), particularlythe normal growth of bone cells (Kvistad et al., 2004). THs also induce the cellular proliferation of cartilage growth in the epiphyseal plate of long bones by stimulation the release of growth hormone (GH) (Kvistad et al., 2004; Sbaihi et al., 2007) and IGF(insulin-growth factor) (Awad, 2002; El-bakry et al., 2010).In addition, thyroid receptors (TRs; $\alpha$ and $\beta$ ) were found in chondrocytes, growth plat, and osteoblasts (Bradley et al., 1992; Ballock et al., 1999; Siddiqi et al., 2002; Bassett and Williams, 2003). It has also been revealed that 3,5,3'-triiodothyronine (T3) can activate the terminal differentiation of growth plate chondrocytes (Ballock et al., 2000), osteoclastic growth and the osteoblasts process (Allain et al., 1992; Britto et al., 1994).

On the other hand, bone shortening due to intrauterine growth retardation could be attributed to the endocrine disorders (Frost, 1987; Awad, 2002). My group reported that maternal hypothyroidism delayed the body growth and ossification in rat (El-bakry et al., 2010). In addition, hypothyroidism can reduce the bone turnover, osteoclast bone reabsorption, osteoblast formation, and remodeling process (Bassett et al., 2010; Cardoso et al., 2014). In general, administration of methimazole (MMI)(Albee et al., 1989), propylthiouracil (PTU)(Tamasy et al., 1986) or carbimazole (CMI) (El-bakry et al., 2010) to rats can cause growth retardation. Alternatively, the hyperthyroidism can accelerate the development of skeletal bones and premature closure of the epiphyseal growth plates (EGPs) (Kosińska et al., 2005), and subsequent diminish the longitudinal bone growth (Allainand McGregor, 1993; Harvey et al., 2002; O'Shea et al., 2003). Hyperthyroidism also results in increasing the osteoclastic response to TH (Jowsey and Gorddan, 1971). Administration of thyroxine (T4) to pre- and postmenopausal women induces the osteogenic and osteoclastic processes (Kosińska et al., 2005), and osteoporotic fractures (Cardoso et al., 2014). In subclinical hyperthyroidism, bone fragility and bone recomposition was observed in the early adverse effect (Bassett and Williams, 2009; Gorka et al., 2013; Cardoso et al., 2014). During the early childhood, severe hyperthyroidism can induce the premature fusion of the sutures of the skull and craniosynostosis (Siddiqi et al., 1997). Low bone density values and high bone resorption rates were demonstrated at diagnosis of hyperthyroidism in children and adolescents (Mora et al, 1999). More importantly, the disturbances in the TR $\alpha 1$ or TR $\beta$ can perturb and delay the development of epiphyseal growth plates and the ossification process (Gothe et al., 1999).

Thus, the maternal thyroid disorders may alter the general skeletal features during the prenatal and postnatal development. Additional examinations are desired to identify the gene expression and signaling of THs-bone axis during the development. Also, several experimental studies are required to test whether T3 can act directly or indirectly in osteoclasts. 


\section{REFERENCES}

Ahmed, O.M., Abd El-Tawab, S.M., Ahmed, R.G., 2010. Effects of experimentally induced maternal hypothyroidism and hyperthyroidism on the development of rat off spring: I- The development of the thyroid hormones-neurotransmitters and adenosinergic system interactions. Int. J. Dev. Neurosci. 28, 437-454.

Ahmed, O.M., Ahmed, R.G., 2012. Hypothyroidism. In A New Look At Hypothyroidism. Dr. D. Springer (Ed.), ISBN:978-953-51-0020-1), In Tech Open Access Publisher, Chapter 1, pp. 1-20.

Ahmed, O.M., Ahmed, R.G., El-Gareib, A.W., El-Bakry, A.M., Abd El-Tawaba, S.M., 2012. Effects of experimentally induced maternal hypothyroidism and hyperthyroidism on the development of rat offspring: II-The developmental pattern of neurons in relation to oxidative stress and antioxidant defense system. Int. J. Dev. Neurosci. 30, 517-537.

Ahmed, O.M., El-Gareib, A.W., El-bakry, A.M., Abd El-Tawab, S.M., Ahmed, R.G., 2008. Thyroid hormones states and brain development interactions. Int. J. Dev. Neurosci. 26(2), 147-209. Review.

Ahmed, R.G., 2011. Perinatal 2, 3, 7, 8-tetrachlorodibenzo-p-dioxin exposure alters developmental neuroendocrine system. Food Chem. Toxicology, 49, 1276-1284.

Ahmed, R.G., 2012a. Maternal-newborn thyroid dysfunction.In the Developmental Neuroendocrinology, pp. 1-369. Ed R.G. Ahmed. Germany: LAP LAMBERT Academic Publishing GmbH \& Co KG.

Ahmed, R.G., 2012b. Maternal-fetal thyroid interactions, Thyroid Hormone, Dr. N.K. Agrawal (Ed.), ISBN: 978-953-51-0678-4, In Tech Open Access Publisher, Chapter 5, pp. 125-156.

Ahmed, R.G., 2013. Early weaning PCB 95 exposure alters the neonatal endocrine system: thyroid adipokine dysfunction. J. Endocrinol. 219 (3), 205-215.

Ahmed, R.G., 2014. Editorial: Do PCBs modify the thyroid-adipokine axis during development? Annals Thyroid Res. 1(1), 11-12.

Ahmed, R.G., 2015a. Chapter 1: Hypothyroidism and brain development. In advances in hypothyroidism treatment.Avid Science Borsigstr.9, 10115 Berlin, Berlin, Germany. Avid Science Publications level 6, Melange Towers, Wing a, Hitec City, Hyderabad, Telangana, India. pp. 1-40.

Ahmed, R.G., 2015b. Hypothyroidism and brain developmental players. Thyroid Research J. 8(2), 1-12.

Ahmed, R.G., 2015c. Editorials and Commentary: Maternofetal thyroid action and brain development. J. of Advances in Biology; 7(1), 1207-1213.

Ahmed, R.G., 2015d. Developmental adipokines and maternal obesity interactions. J. of Advances in Biology; 7(1), 1189-1206.

Ahmed, R.G., 2016a. Gestational dexamethasone alters fetal neuroendocrine axis. Toxicology Letters, 258, 46-54.

Ahmed, R.G., 2016b. Neonatal polychlorinated biphenyls-induced endocrine dysfunction. Ann. Thyroid. Res. 2 (1), 34-35.

Ahmed, R.G., 2016c. Maternal iodine deficiency and brain disorders. Endocrinol. Metab. Syndr. 5, 223.http:// dx.doi.org/10.4172/2161-1017.1000223.

Ahmed, R.G., 2016d. Maternal bisphenol A alters fetal endocrine system: Thyroid adipokine dysfunction. Food Chem. Toxicology, 95, 168-174.

Ahmed, R.G., 2017a. Developmental thyroid diseases and GABA ergic dysfunction. EC Neurology 8.1, 02-04. 
Maternal Thyroid Dysfunctions and Neonatal Bone Maldevelopment

Ahmed, R.G., 2017b. Hyperthyroidism and developmental dysfunction. Arch Med. 9, 4.

Ahmed, R.G., 2017c. Anti-thyroid drugs may be at higher risk for perinatal thyroid disease. EC Pharmacology and Toxicology 4.4, 140-142.

Ahmed, R.G., 2017d. Perinatal hypothyroidism and cytoskeleton dysfunction. Endocrinol Metab Syndr 6, 271. doi:10.4172/2161-1017.1000271

Ahmed, R.G., 2017e. Developmental thyroid diseases and monoaminergic dysfunction. Advances in Applied Science Research 8(3), 01-10.

Ahmed, R.G., 2017f. Hypothyroidism and brain development. J. Anim Res Nutr. 2(2), 13.

Ahmed, R.G., 2017g. Antiepileptic drugs and developmental neuroendocrine dysfunction: Every why has A Where fore. Arch Med 9(6), 2.

Ahmed, R.G., 2017h. Gestational prooxidant-antioxidant imbalance may be at higher risk for postpartum thyroid disease. Endocrinol Metab Syndr 6, 279. doi:10.4172/2161-1017.1000279.

Ahmed, R.G., 2017i. Synergistic actions of thyroid-adipokines axis during development. Endocrinol Metab Syndr 6, 280. doi:10.4172/2161-1017.1000280.

Ahmed, R.G., 2017j. Thyroid-insulin dysfunction during development. International Journal of Research Studies in Zoology 3(4), 73-75. DOI: http://dx.doi.org/10.20431/2454-941X.0304010.

Ahmed, R.G., 2017k. Developmental thyroid diseases and cholinergic imbalance. International Journal of Research Studies in Zoology 3(4), 70-72. DOI: http://dx.doi.org/10.20431/2454-941X.0304009.

Ahmed, R.G., 2017l. Thyroid diseases and developmental adenosinergic imbalance. Int J Clin Endocrinol 1(2), 053-055.

Ahmed, R.G., 2017m. Maternal anticancer drugs and fetal neuroendocrine dysfunction in experimental animals. Endocrinol Metab Syndr 6, 281. doi:10.4172/2161-1017.1000281.

Ahmed, R.G., 2017n. Letter: Gestational dexamethasone may be at higher risk for thyroid disease developing peripartum. Open Journal of Biomedical \& Life Sciences (Ojbili) 3(2), 01-06.

Ahmed, R.G., 2017o. Deiodinases and developmental hypothyroidism. EC Nutrition 11.5, 183-185.

Ahmed, R.G., 2017p. Maternofetal thyroid hormones and risk of diabetes. Int. J. of Res. Studies in Medical and Health Sciences 2(10), 18-21.

Ahmed, R.G., 2017r. Association between hypothyroidism and renal dysfunctions. International Journal of Research Studies in Medical and Health Sciences 2(11), 1-4.

Ahmed, R.G., 2017s. Maternal hypothyroidism and lung dysfunction. International Journal of Research Studies in Medical and Health Sciences 2(11), 8-11.

Ahmed, R.G., 2017t. Endocrine disruptors; possible mechanisms for inducing developmental disorders. International journal of basic science in medicine (IJBSM)2(4), 157-160.

Ahmed, R.G., 2017u. Maternal thyroid hormones trajectories and neonatal behavioral disorders. ARC Journal of Diabetes and Endocrinology 3(2), 18-21.

Ahmed, R.G., 2017v. Maternal thyroid dysfunction and neonatal cardiac disorders. Insights Biol Med. 1, 092-096.

Ahmed, R.G., 2018a. Maternal hypothyroidism and neonatal testicular dysfunction. International Journal of Research Studies in Medical and Health Sciences 3(1), 8-12. 
Maternal Thyroid Dysfunctions and Neonatal Bone Maldevelopment

Ahmed, R.G., 2018b. Maternal hypothyroidism and neonatal depression: Current perspective. International Journal of Research Studies in Zoology 4(1), 6-10. DOI: http://dx.doi.org/10.20431/2454-941X.0401002.

Ahmed, R.G., 2018c. Non-genomic actions of thyroid hormones during development. App Clin Pharmacol Toxicol: ACPT-108. DOI: 10.29011/ACPT-109. 100008.

Ahmed, R.G., 2018d. Maternal thyroid function and placental hemodynamics. ARC Journal of Animal and Veterinary Sciences 4(1), 9-13. DOI: http://dx.doi.org/10.20431/2455-2518.0401002.

Ahmed, R.G., 2018e. Interactions between thyroid and growth factors during development. ARC Journal of Diabetes and Endocrinology 4(1), 1-4. DOI: http://dx.doi.org/10.20431/2455-5983.0401001.

Ahmed, R.G., 2018f. Maternal thyroid hormones and neonatal appetite. ARC Journal of Nutrition and Growth 4(1), 18-22. DOI: http://dx.doi.org/10.20431/2455-2550.0401005.

Ahmed, R.G., 2018g. Genomic actions of thyroid hormones during development. ARC Journal of Diabetes and Endocrinology 4(1), 5-8. DOI: http://dx.doi.org/10.20431/2455-5983.0401002.

Ahmed, R.G., 2018h. Dysfunction of maternal thyroid hormones and psychiatric symptoms. American Research Journal of Endocrinology. 2(1), 1-6.

Ahmed, R.G., 2018i. Is there a connection between maternal hypothyroidism and developing autism spectrum disorders? ARC Journal of Neuroscience 3(1), 5-8. DOI: http://dx.doi.org/10.20431/2456-057X.0301002.

Ahmed, R.G., Abdel-Latif, M., Ahmed F., 2015b. Protective effects of GM-CSF in experimental neonatal hypothyroidism. International Immunopharmacology 29, 538-543.

Ahmed, R.G., Abdel-Latif, M., Mahdi, E., El-Nesr, K., 2015a. Immune stimulation improves endocrine and neural fetal outcomes in a model of maternofetal thyrotoxicosis. Int. Immunopharmacol. 29, 714-721.

Ahmed, R.G., Davis, P.J., Davis, F.B., De Vito, P., Farias, R.N., Luly, P., Pedersen, J.Z., Incerpi, S., 2013b. Nongenomic actions of thyroid hormones: from basic research to clinical applications. An update. Immunology, Endocrine \& Metabolic Agents in Medicinal Chemistry, 13(1), 46-59.

Ahmed, R.G., El-Gareib, A.W. 2014. Lactating PTU exposure: I- Alters thyroid-neural axis in neonatal cerebellum. Eur. J. of Biol. and Medical Sci. Res. 2(1), 1-16.

Ahmed, R.G., El-Gareib, A.W., 2017. Maternal carbamazepine alters fetal neuroendocrine-cytokines axis. Toxicology 382, 59-66.

Ahmed, R.G., El-Gareib, A.W., Incerpi, S., 2014. Lactating PTU exposure: II- Alters thyroid-axis and prooxidantantioxidant balance in neonatal cerebellum. Int. Res. J. of Natural Sciences 2(1), 1-20.

Ahmed, R.G.,El-Gareib, A.W., Shaker, H.M., 2018. Gestational 3,3',4,4',5-pentachlorobiphenyl (PCB 126) exposure disrupts fetoplacental unit: Fetal thyroid-cytokines dysfunction. Life Sciences 192, 213-220.

Ahmed, R.G., Incerpi, S., 2013. Gestational doxorubicin alters fetal thyroid-brain axis. Int. J. Devl. Neuroscience 31, 96-104.

Ahmed, R.G., Incerpi, S., Ahmed, F., Gaber, A., 2013a. The developmental and physiological interactions between free radicals and antioxidant: Effect of environmental pollutants. J. of Natural Sci. Res. 3(13), 74-110.

Albee, R.R., Mattsson, J.L., Johnson, K.A., Kirk, H.D., Breslin, W.J., 1989. Congenital hypothyroidism in rats. Neurotoxicol. Teratol. 11, 171-183.

Allain, T.J., Chambers, T.J., Flanagan, A.M., Mc Gregor, A.M., 1992. Tri-iodothyronine stimulates rat osteoclastic bone resorption by an indirect effect. J Endocrinol 133, 327-331.

American Research Journal of Endocrinology

Page 4 
Maternal Thyroid Dysfunctions and Neonatal Bone Maldevelopment

Allain, T.J., McGregor, A.M., 1993. Thyroid hormones and bone. J Endocrinol 139, 9-18.

Awad, M.F.I., 2002. Increased risk of fetal anomalies following maternally induced hypothyroidism in female albino rats. Ph.D. Thesis, Fac. of Sci., Cairo Univ., Egypt.

Ballock, R., Mita, B.C., Zhou, X., Chen, D.H., Mink, L.M., 1999. Expression of thyroid hormone receptor isoforms in rat growth plate cartilage in vivo. J Bone Miner Res 14, 1550-1556.

Ballock, R.T., Zhou, X., Mink, L.M., Chen, D.H., Mita, B.C., Stewart, M.C., 2000. Expression of cyclin-dependent kinase inhibitors in epiphyseal chondrocytes induced to terminally differentiate with thyroid hormone. Endocrinology 141, 4552-7.

Bassett, J.H., Boyde. A., Howell, P.G., Bassett, R.H., Galliford, T.M., Archanco, M., 2010. Optimal bone strength and mineralization requires the type 2 iodothyronine deiodinase in osteoblasts. Proc Natl AcadSci USA. 107(16), 7604-9.

Bassett, J.H., Williams, G.R., 2003. The molecular actions of thyroid hormone in bone. Trends Endocrinol Metab $14,356-364$.

Bassett, J.H., Williams, G.R., 2009. The skeletal phenotypes of TR alpha and TR beta mutant mice. J Mol Endocrinol. 42, 269-282.

Bradley, D.J., Towle, H.C., Young, W.S., 1992. Spatial and temporal expression of alpha- and beta-thyroid hormone receptor mRNAs, including the beta 2-subtype, in the developing mammalian nervous system.J Neurosci $12,2288-2302$.

Britto, J.M., Fenton, A.J., Holloway, W.R., Nicholson, G.C., 1994) Osteoblasts mediate thyroid hormone stimulation of osteoclastic bone resorption. Endocrinology 134, 169-176.

Candelotti, E., De Vito, P., Ahmed, R.G., Luly, P., Davis, P.J., Pedersen, J.Z., Lin, H-Y., Incerpi, I., 2015. Thyroid hormones crosstalk with growth factors: Old facts and new hypotheses. Immun., Endoc. \& Metab. Agents in Med. Chem., 15, 71-85.

Cardoso, L.F., Maciel, L.M.Z., de Paula, F.J.A., 2014. The multiple effects of thyroid disorders on bone and mineral metabolism. Arq Bras Endocrinol Metab. 58(5), 452-463.

De Vito, P., Candelotti, E., Ahmed, R.G., Luly, P., Davis, P.J., Incerpi, S., Pedersen, J.Z., 2015. Role of thyroid hormones in insulin resistance and diabetes. Immun., Endoc. \& Metab. Agents in Med. Chem., 15, 86-93.

El-bakry, A.M., El-Ghareeb, A.W., Ahmed, R.G., 2010. Comparative study of the effects of experimentally-induced hypothyroidism and hyperthyroidism in some brain regions in albino rats. Int. J. Dev. Neurosci. 28, 371-389.

El-Ghareeb, A.A., El-Bakry, A.M., Ahmed, R.G., Gaber, A., 2016. Effects of zinc supplementation in neonatal hypothyroidism and cerebellar distortion induced by maternal carbimazole. Asian Journal of Applied Sciences 4(04), 1030-1040.

Frost, H.M., 1987. The mechanostat: A proposed mechanism of osteoporoses and the bone mass effects of mechanical and non-mechanical agents. Bone Mineral 2, 73-85.

Gorka, J., Taylor-Gjevre, R.M., Arnason, T., 2013.Metabolic and clinical consequences of hyperthyroidism on bone density. Int J Endocrinol. 2013, 638727.

Gothe, S., Wang, Z., Ng, L., Kindblom, J.M., Barros, A.C., Ohlsson, C., Vennstrom, B., Forrest, D., 1999. Mice devoid of all known thyroid hormone receptors are viable but exhibit disorders of the pituitary-thyroid axis, growth, and bone maturation. Genes Dev 13, 1329-1341. 
Harvey, C.B., O’Shea, P.J., Scott, A.J., Robson, H., Siebler, T., Shalet, S.M., Samarut, J., Chassande, O., Williams, G.R., 2002. Molecular mechanisms of thyroid hormone effects on bone growth and function. Mol Genet Metab $75,17-30$.

Incerpi, S., Hsieh, M-T., Lin, H-Y., Cheng, G-Y., De Vito, P., Fiore, A.M., Ahmed, R.G., Salvia, R., Candelotti, E., Leone, S., Luly, P., Pedersen, J.Z., Davis, F.B., Davis, P.J., 2014. Thyroid hormone inhibition in L6 myoblasts of IGF-Imediated glucose uptake and prolife ration: new roles for integr in $\alpha v \beta 3$. Am. J. Physiol. Cell Physiol. 307, C150-C161.

Jowsey, J., Gorddan, G., 1971. Bone turnover and osteoporosis. In: The Biochemistry and Physiology of Bone, 2nd edition, by Bourne, G.H., vol. III, development and growth, Academic Press, New York/London, p. 204.

Kosińska, A., Syrenicz, A., Syrenicz, M., Kosin' ski, B., Miazgowski, T., Garanty-Bogacka, B., 2005. The influence of treatment with substitutive or suppressive doses of thyroxine on biochemical bone turnover markers. Ann. Acad. Med. Stetin. 51 (2), 97-104.

Kvistad, P.H., Lovas, K., Boman, H., Myking, O.L., 2004. Retarded bone growth in thyroid hormone resistance. A clinical study of a large family with a novel thyroid hormone receptor mutation. Eur. J. Endocrinol. 150 (4), 425-430.

O’Shea, P.J., Harvey, C.B., Suzuki, H., Kaneshige, M., Kaneshige, K., Cheng, S.Y., Williams, G.R., 2003. A thyrotoxic skeletal phenotype of advanced bone formation in mice with resistance to thyroid hormone. Mol Endocrinol $17,1410-1424$.

Sbaihi, M., Kacem, A., Aroua, S., Baloche, S., Rousseau, K., Lopez, E., Meunier, F., Dufour, S., 2007. Thyroid hormoneinduced demineralisation of the vertebral skeleton of the eel, Anguilla anguilla. Gen. Comp. Endocrinol. 151 (1), 98-107.

Siddiqi, A., Burrin, J.M., Noonan, K., James, I., Wood, D.F., Price, C.P., Monson, J.P., 1997. A longitudinal study of markers of bone turnover in Graves' disease and their value in predicting bone mineral density. J Clin Endocrinol Metab. 82, 753-759.

Siddiqi, A., Parsons, M.P., Lewis, J.L., 2002. TR expression and function in human bone marrow stromal and osteoblast- like cells. J Clin Endocrinol Metab 87, 906-914.

Tamasy, V., Meisami, E., Vallerga, A., Timiras, P.S., 1986. Rehabilitation from neonatal hypothyroidism: Spontaneous motor activity, exploratory behavior, avoidance learning and responses of pituitary-thyroid axis to stress in male rats. Psychoneuroendocrinol. 11, 91-103.

Van Herck, S.L.J., Geysens, S., Bald, E., Chwatko, G., Delezie, E., Dianati, E., Ahmed, R.G., Darras, V.M., 2013. Maternal transfer of methimazole and effects on thyroid hormone availability in embryonic tissues. Endocrinol. 218, 105-115.

Citation: Ahmed R.G. "Maternal Thyroid Dysfunctions and Neonatal Bone Maldevelopment". American Research Journal of Endocrinology; 2(1); 1-6.

Copyright (C) 2018 Ahmed R.G., This is an open access article distributed under the Creative Commons Attribution License, which permits unrestricted use, distribution, and reproduction in any medium, provided the original work is properly cited. 